\title{
Comparison of the radiopacity of selected materials used for vital pulp therapy: An in vitro assessment
}

\section{Porównanie pochłaniania promieni rentgenowskich przez wybrane materiały stosowane w leczeniu biologicznym miazgi - ocena in vitro}

\author{
Elżbieta Łuczaj-Cepowicz ${ }^{1, A-E}$, Grażyna Marczuk-Kolada ${ }^{1, A-E}$, Małgorzata Pawińska ${ }^{2, D, E}$, Janusz Różyckiji,B,C, Ewa Chorzewska ${ }^{1, E}$ \\ 1 Department of Pedodontics, Medical University of Bialystok, Poland \\ ${ }^{2}$ Department of Integrated Dentistry, Medical University of Bialystok, Poland \\ ${ }^{3}$ Department of Radiology, Medical University of Bialystok, Poland \\ A - research concept and design; $\mathrm{B}$ - collection and/or assembly of data; $\mathrm{C}$ - data analysis and interpretation; \\ $D$ - writing the article; $E$ - critical revision of the article; $F$ - final approval of the article
}

Address for correspondence

Grażyna Marczuk-Kolada

E-mail: grazyna.kolada@umb.edu.pl

\section{Funding sources}

None declared

Conflict of interest

None declared

Received on February 5, 2019

Reviewed on April 9, 2019

Accepted on May 21, 2019

Published online on August 7, 2019

Cite as

Łuczaj-Cepowicz E, Marczuk-Kolada G, Pawińska M, Różycki J, Chorzewska E. Comparison of the radiopacity of selected materials used for vital pulp therapy: An in vitro assessment. Dent Med Probl. 2019;56(3):285-290.

doi:10.17219/dmp/109550

DOI

$10.17219 / \mathrm{dmp} / 109550$

Copyright

○ 2019 by Wroclaw Medical University

This is an article distributed under the terms of the

Creative Commons Attribution 3.0 Unported License (CC BY 3.0)

(https://creativecommons.org/licenses/by/3.0/)

\begin{abstract}
Background. An assessment of the therapeutic effects of vital pulp treatment is based on both clinical and radiological evaluation.

Objectives. The aim of the research was a long-term (after 1, 2, 4, 6, and 8 weeks) radiological assessment of X-ray absorption by 8 selected materials used for the vital treatment of dental pulp.

Material and methods. The materials, prepared in accordance with the manufacturers' recommendations, were placed in molds measuring $10 \mathrm{~mm}$ in diameter and $2 \mathrm{~mm}$ in thickness. The molds with the samples were placed on an occlusal film with an aluminum step wedge, and then X-rayed using an intraoral X-ray unit. After processing, an X-ray image with varying degrees of opacity was obtained. The radiological density of the samples, the step wedge and the background was measured 6 times using a densitometer. The tests were repeated at the following intervals: after 7 days, and after 2, 4, 6, and 8 weeks. The molds with the material samples were stored in an incubator at $37^{\circ} \mathrm{C}$ and $95 \%$ humidity.

Results. The obtained results were statistically analyzed. The mineral trioxide aggregate (MTA) materials exhibited the highest degree of contrast, whereas the lowest radiopacity was shown for the non-setting calcium hydroxide preparations $(p<0.0001)$. Calcium hydroxide cements presented medium radiopacity values.

Conclusions. The radiopacity of all the evaluated materials showed a statistically insignificant increasing tendency with regard to the duration of the experiment. All the tested preparations showed acceptable radiopacity, enabling radiological detection in the course of vital pulp therapy.

Key words: mineral trioxide aggregate, densitometry, calcium hydroxide, X-ray absorption, vital dental pulp therapy

Słowa kluczowe: agregat trójtlenków mineralnych, densytometria, wodorotlenek wapnia, pochłanianie promieni rentgenowskich, leczenie biologiczne miazgi zębów
\end{abstract}




\section{Introduction}

The aim of conservative dental pulp treatment is to maintain the function of the dentin pulp complex, which enables healing and dentin bridge formation. Additionally, in the case of teeth with incomplete root development, viable, healthy crown and root pulp ensures normal apexogenesis. ${ }^{1}$ Although viable pulp preservation in carious pulp exposure is controversial, such management is commonly accepted in teeth with incomplete root development. ${ }^{1,2}$

The use of pulp-coating materials, marked by biocompatibility, insolubility in tissue fluids, antibacterial activity, long-term sealing ability, and mechanical strength as well as the ability to stimulate and form mineralized tissues, is one of the conditions for successful vital pulp treatment. Until recently, non-setting calcium hydroxide preparations were conventionally used for this purpose. However, due to some defects of these materials, such as poor adhesion to dentin, rapid loss of sealing ability, high solubility, low mechanical strength, and tunnel defects in dentin bridges, research has been conducted to develop other preparations. ${ }^{1,3}$ In order to eliminate these defects, setting calcium hydroxide cements were developed. Although improved dentin adherence, higher mechanical strength and lower solubility were achieved, tunnel defects in dentin bridges have still not been eliminated. ${ }^{4,5}$ In the 1990 s, mineral trioxide aggregate (MTA), which showed very good sealing properties, mechanical strength and low solubility, was introduced into the vital treatment of dental pulp. ${ }^{6}$ It was also observed that the reparative dentin formed upon contact with MTA was homogeneous. ${ }^{4}$
An assessment of the therapeutic effects of vital pulp treatment is based on both clinical and radiological evaluation. Only radiological evaluation allows tracing the formation of mineralized tissues at the site of contact with the therapeutic material as well as the progress of apexogenesis in the case of teeth with incomplete root development. The degree of X-ray absorption seems to be an important characteristic of these preparations, enabling their differentiation from mineralized dental tissues. The process of formation of these tissues is of varying duration due to the effects of odontotropic medication. ${ }^{7}$ In the case of calcium hydroxide, mineralized barrier formation was observed not earlier than after 30 days, although most authors report longer periods, i.e., at least 60 days. $^{8}$ The use of MTA accelerates the healing process with a hard tissue bridge being formed, which, according to Parolia et al., becomes noticeable after $15-45$ days. ${ }^{9}$

Therefore, a long-term radiological assessment of X-ray absorption by the abovementioned materials seems to be of importance.

\section{Material and methods}

\section{Preparation of test specimens}

The 8 materials included in this study were: MTA Angelus White ${ }^{\circledR}$ (Angelus Indústria de Produtos Odontológicos S/A, Londrina, Brazil); MTA Angelus Grey ${ }^{\circledR}$ (Angelus Indústria de Produtos Odontológicos S/A);

Table 1. Composition of evaluated materials as provided by the manufacturers

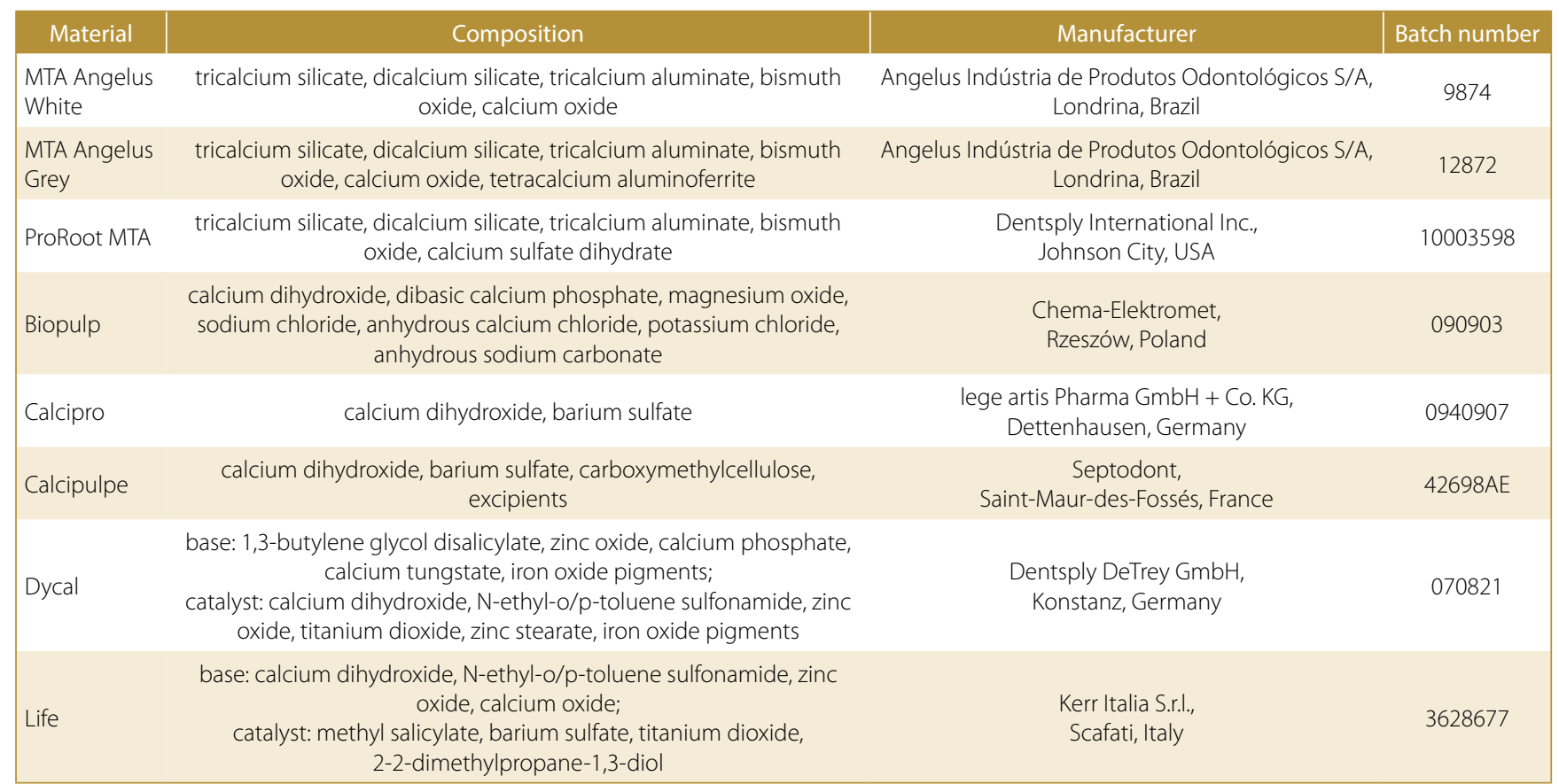


ProRoot $^{\circledR}$ MTA (Dentsply International Inc., Johnson City, USA); Biopulp ${ }^{\circledR}$ (Chema-Elektromet, Rzeszów, Poland); Calcipro ${ }^{\circledR}$ (lege artis Pharma $\mathrm{GmbH}+$ Co. KG, Dettenhausen, Germany); Calcipulpe ${ }^{\circledR}$ (Septodont, SaintMaur-des-Fossés, France); Dycal ${ }^{\circledR}$ (Dentsply DeTrey GmbH, Konstanz, Germany); and Life ${ }^{\circledR}$ (Kerr Italia S.r.l., Scafati, Italy). The main components of each material are described in Table 1 . The materials were placed in molds, which allowed obtaining samples that were $10 \mathrm{~mm}$ in diameter and $2 \mathrm{~mm}$ in thickness.

\section{Evaluation of the radiopacity of the tested materials}

The molds with the samples were placed on a Kodak occlusal film, size 4, with D speed (Caresteam Health France, Noisy-le-Grand, France) with an aluminum step wedge, and then X-rayed using a Planmeca Intra ${ }^{\circledR}$ intraoral X-ray unit (Planmeca Oy, Helsinki, Finland) with the following exposure parameters: $70 \mathrm{kV}$ and $8 \mathrm{~mA}$. The distance between the tube and the film surface was $30 \mathrm{~cm}$. The exposure time was selected experimentally using a step wedge filter. The aluminum step wedge, made of $99 \%$ pure aluminum, with 16 incremental steps, each 1-millimeter-thick, was used as a standard for comparing the radiodensity of the tested materials and controlling for any variations in exposure and processing (Fig. 1).

After irradiation, the films were processed in an XR 25S automatic imager (Dürr Dental SE, Bietigheim-Bissingen, Germany). Processing was done using freshly prepared original chemical reagents. This way, an X-ray image with varying degrees of opacity was obtained. The radiological density of the samples, the step wedge and the background was measured 6 times using a Duolight A densitometer, v. 2.47 (IBA Dosimetry GmbH, Schwartzenbruck, Germany), choosing places with a homogeneous structure.

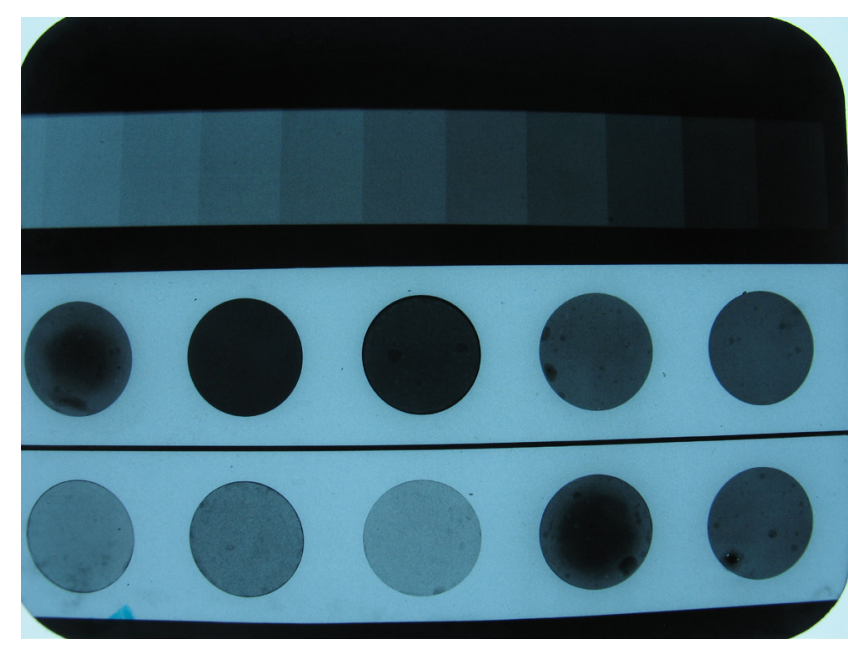

Fig. 1. Radiograph with sample disks of the freshly prepared study materials and the aluminum step wedge
The obtained results were presented in a numerical form as mean radiodensity. The tests were repeated at the following intervals: after 7 days, and after 2, 4, 6, and 8 weeks. The molds with the material samples were stored between the subsequent tests in an incubator at $37^{\circ} \mathrm{C}$ and 95\% humidity.

In order to determine the radiopacity of the 2-millimeter-thick samples of the tested materials, a calibration curve for the step wedge was generated (creating a regression curve for the aluminum step wedge). The radiopacity of the specimens was expressed in terms of the equivalent thickness of aluminum, according to the methodology presented by other authors. ${ }^{10-12}$ The comparison of the numerical values obtained during the irradiation of the tested materials and from the step wedge filter made it possible to determine the degree of $\mathrm{X}$-ray absorption by evaluating the preparations relative to the thickness of the $\mathrm{X}$-rayed aluminum.

\section{Statistical analysis}

The statistical analysis was performed using the Statistica, v. 8.0 (StatSoft Inc., Tulsa, USA) software package. The data was analyzed by means of the analysis of variance (ANOVA) and the post hoc Tukey test. The level of significance was set at $p<0.05$.

\section{Results}

The mean values and standard deviations of radiopacity, expressed in mm of aluminum thickness, for all materials at 6 time points are shown in Fig. 2.

Mineral trioxide aggregate exhibited the highest degree of radiopacity. Among the MTA products, MTA Angelus Grey showed significantly higher radiopacity at all time points $(p<0.0001)$. No significant differences were found in the radiopacity of MTA Angelus White and ProRoot MTA after 2, 4 and 6 weeks only.

The lowest radiopacity was shown for the nonsetting calcium hydroxide preparations. No significant differences were found between Biopulp and Calcipro at any time points. Calcipulpe showed higher radiopacity compared to other non-setting calcium hydroxide materials, but only at 2 and 4 weeks after preparation. Calcium hydroxide cements - Life and Dycal - had medium radiopacity values compared to the previously described groups. No statistically significant differences were found between Life and Dycal at any study time points. All other differences in radiopacity at different study time points were highly significant $(p<0.0001)$.

The changes in the radiopacity of the study materials throughout the experiment are shown in Fig. 3. The radiopacity of all the evaluated materials showed a statistically insignificant increasing tendency. 


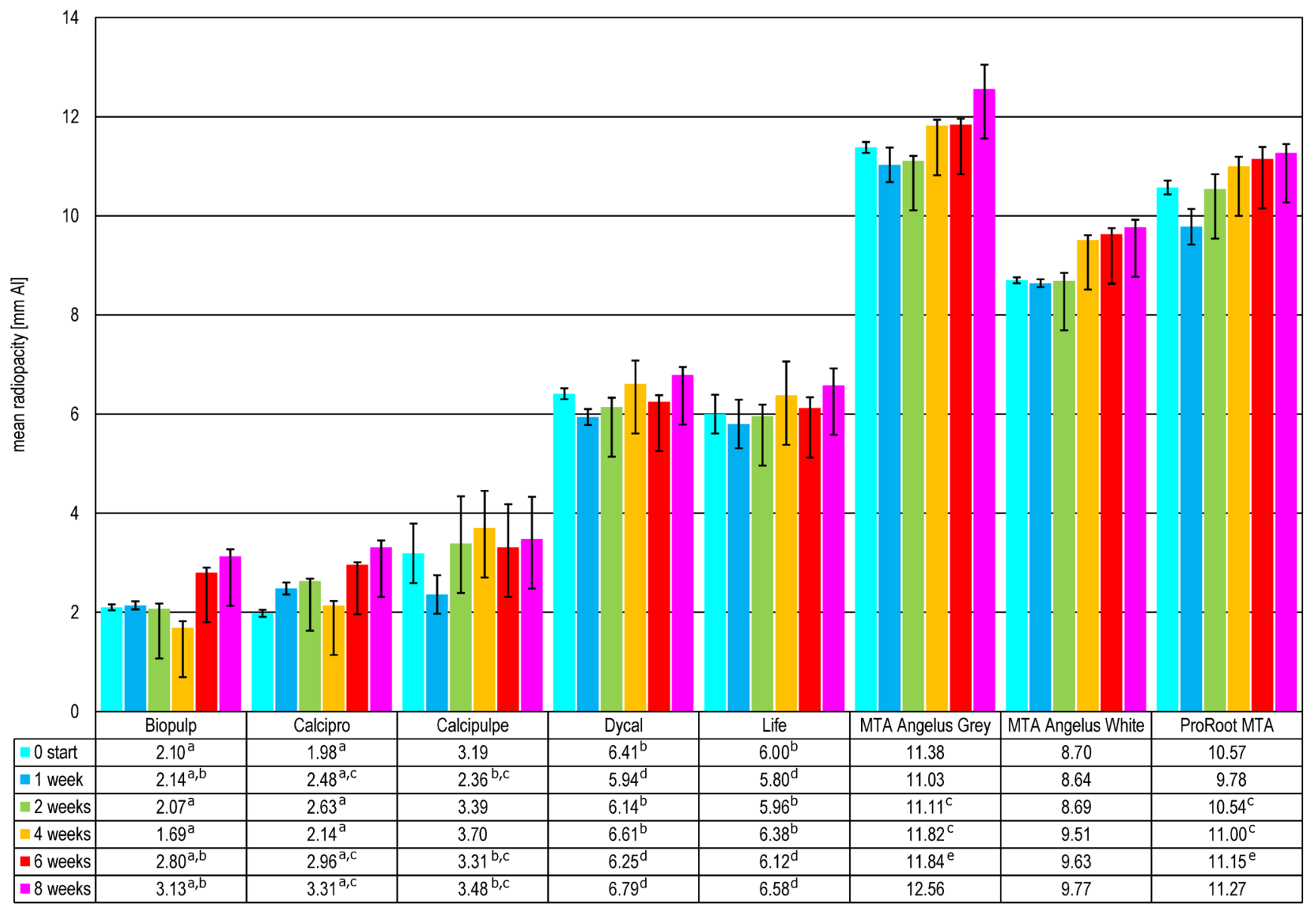

Fig. 2. Mean values and standard deviations of radiopacity for all materials at 6 time points

Values which have not been tagged with identical superscript letters in the same line indicate statistically significant differences at $p<0.0001$; values which have been tagged with identical superscript letters in the same line show statistically insignificant differences $(p>0.05)$.

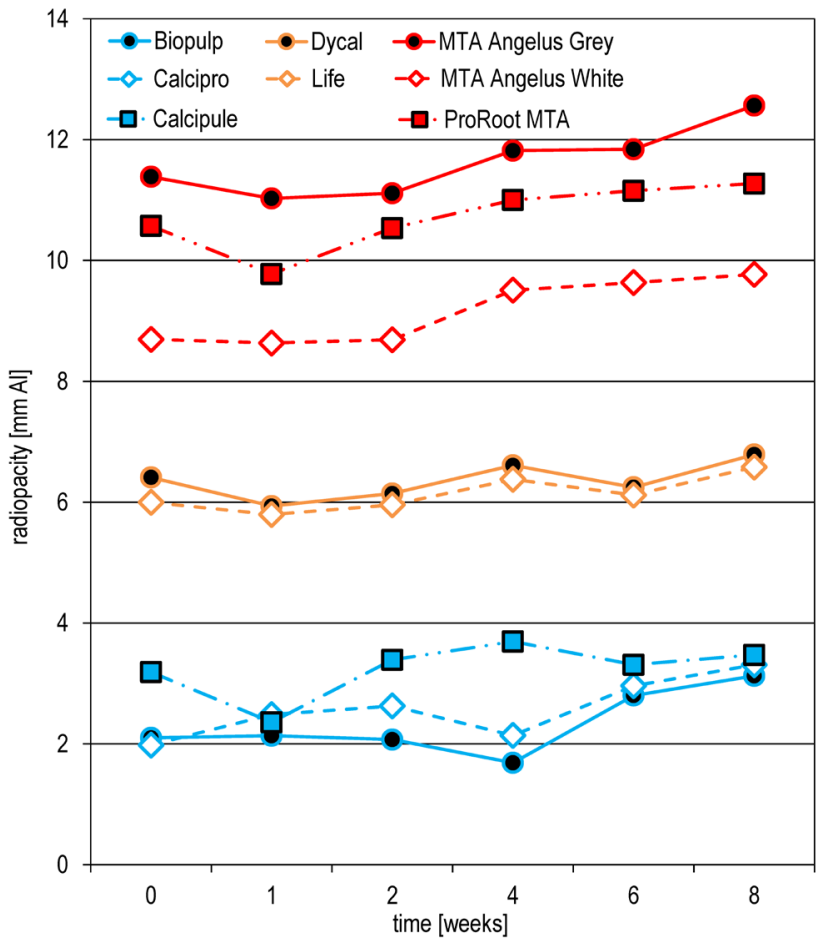

Fig. 3. Radiopacity of the study materials throughout the duration of the experiment

\section{Discussion}

The ability to absorb X-rays - radiopacity - is an important and required feature of materials used in dental treatment. The use of an aluminum step wedge is recommended as a reference standard. According to ISO $6876 / 2001$ specifications, a step wedge should have a purity of at least $98 \%$ aluminum. ${ }^{13}$ It has been used with an occlusal film in most published studies to determine the optical density of materials. ${ }^{10,11,14,15}$ We used this method in our experiment to determine the radiopacity of materials used in the vital treatment of dental pulp.

Some authors have compared the radiopacity of materials to that of mineralized dental tissues (enamel and dentin). ${ }^{16-18}$ However, the optical density of both enamel and dentin is variable. It depends on the patient's age and the individual degree of tissue mineralization. The storage method for the removed tooth used for comparisons also seems important. ${ }^{16}$ Furthermore, it has been demonstrated that the radiopacity of pure aluminum is similar to that of human dentin. ${ }^{12}$ Thus, we only used a step wedge in our study.

However, studies on the radiopacity of dental materials conducted by other authors are not unanimous regarding the thickness of the analyzed samples. Samples 
of a thickness from 0.5 up to $2.5 \mathrm{~mm}$ have been evaluated. ${ }^{11,15,19-21}$ According to Watts and McCabe, using 2-millimeter-thick samples is one of the ways to obtain good contrast in relation to the degree of shading of the film background. ${ }^{12}$ We used the same sample thickness in our study, similarly to other authors. ${ }^{19}$

According to ISO standards, the radiopacity of dental cements should be equal to or higher than that of aluminum of the same thickness. ${ }^{16}$ We found no studies in the available literature comparing the groups of materials or observing the time points described in our experiment. In our study, we evaluated the radiopacity of fresh samples at baseline, and then 5 times - after 1, 2, 4, 6, and 8 weeks. We believe that a long-term radiopacity assessment of the materials used in vital pulp treatment is important from a clinical practice point of view. According to the literature, the duration of hard tissue bridge mineralization is from 21 to 60 days. ${ }^{8,9,22}$ This depends on the type of material used. In our experiment, we used 3 groups of materials, and therefore, the observation period was prolonged to 8 weeks. In the available literature, only Cutajar et al. presented the radiopacity observations of MTA 7 and 28 days after preparation. ${ }^{23}$ In other studies, the materials were evaluated once, immediately after preparation ${ }^{18,24-26}$ or after setting. ${ }^{11}$ However, Islam et al. ${ }^{27}$ and Chng et al. ${ }^{28}$ measured the MTA radiopacity 4 times - from baseline (fresh samples) until complete setting.

In our experiment, the first radiopacity assessment was performed immediately after preparation. Only a fresh sample from Calcipro, despite the addition of barium sulfate, showed lower radiopacity, with an aluminum equivalent value of $1.98 \mathrm{~mm}$. Other tested non-setting calcium hydroxide materials reached the minimum required radiopacity, ranging from 2.10 to $3.19 \mathrm{~mm} \mathrm{Al}$. This result is difficult to interpret. Manufacturers do not provide full ingredient lists; they only use terms such as 'excipients'. This may suggest that other ingredients besides barium sulfate influence radiopacity, which is confirmed by the literature data. ${ }^{26}$ The authors also noted that non-setting calcium hydroxide materials are characterized by high X-ray permeability. ${ }^{18}$ The most radiopaque materials among the tested objects were the MTA preparations, with radiopacity ranging from 8.70 to $11.38 \mathrm{~mm} \mathrm{Al}$. Laghios et al. showed lower radiopacity of MTA samples of $2 \mathrm{~mm}(6.43 \mathrm{~mm} \mathrm{Al})$ than what we observed in our study. ${ }^{24}$ This may be due to different exposure conditions. Other authors made similar observations. ${ }^{27,28} \mathrm{Kim}$ et al. found high radiopacity of 1-millimeter-thick samples of ProRoot MTA (6.92 mm Al). ${ }^{25}$ Researchers who evaluated samples after setting also showed high radiopacity of MTA. ${ }^{14,29}$ Differences in radiopacity between the assessed MTA preparations, despite similar bismuth oxide content, could be the result of varying chemical compound proportions in the materials. ${ }^{30}$ Setting calcium hydroxide cements - Dycal and Life - obtained radiopacity values lower than MTA preparations $(6.41 \mathrm{~mm} \mathrm{Al}$ and $6.00 \mathrm{~mm} \mathrm{Al}$, respectively).
Both these cements belong to a group showing medium radiopacity values, as confirmed by Devito et al. ${ }^{15}$ Life and Dycal showed similar radiopacity despite certain differences in their chemical composition.

While analyzing the changes in the radiopacity of each of the evaluated preparations during the 8-week experiment, we noticed that the optical density of all materials increased insignificantly. Our study showed a steady, insignificant increase in optical density 6 and 8 weeks after sample preparation. Also, all materials exceeded the minimum values of recommended radiopacity.

Difficulties in determining the detailed concentrations of radiopaque substances in the tested materials and problems with the simulation of the oral environment may be possible limitations of the present study.

\section{Conclusions}

Within the limitations of the present study, based on the obtained results, the tested materials can be divided into 3 groups in terms of their radiopacity. The highest radiopacity was produced by the MTA preparations, followed by the setting calcium hydroxide materials, and was the lowest in the non-setting calcium hydroxide group.

To conclude, considering that a material must be radiopaque, a clinician must pay careful attention to the chemical composition characteristic to a certain group of preparations. It can be stated that all the tested preparations showed acceptable radiopacity, enabling radiological detection during vital pulp therapy. However, radiopacity is only one of the components that affect the efficacy of therapeutic procedures. Therefore, other factors determining the choice of therapeutic materials should also be taken into account.

\section{ORCID iDs}

Elżbieta Łuczaj-Cepowicz (1) https://orcid.org/0000-0002-3055-5918 Grażyna Marczuk-Kolada (i) https://orcid.org/0000-0002-2344-9922 Małgorzata Pawińska (1) https://orcid.org/0000-0003-0044-638X Janusz Różycki (1) https://orcid.org/0000-0002-6423-5365 Ewa Chorzewska (1) https://orcid.org/0000-0003-2464-5316

\section{References}

1. Nosrat A, Seifi A, Asgary S. Pulpotomy in caries-exposed immature permanent molars using calcium-enriched mixture cement or mineral trioxide aggregate: A randomized clinical trial. Int J Paediatr Dent. 2013;23(1):56-63.

2. Witherspoon DE. Vital pulp therapy with new materials: New directions and treatment perspectives - permanent teeth. J Endod. 2008;34(7 Suppl):S25-S28.

3. Paranjpe $A$, Zhang $H$, Johnson JD. Effects of mineral trioxide aggregate on human dental pulp cells after pulp-capping procedures. J Endod. 2010;36(6):1042-1047.

4. Nair PN, Duncan HF, Pitt Ford TR, Luder HU. Histological, ultrastructural and quantitative investigations on the response of healthy human pulps to experimental capping with mineral trioxide aggregate: A randomized controlled trial. Int Endod J. 2008;41(2):128-150.

5. Swift EJ Jr., Trope M, Ritter AV. Vital pulp therapy for the mature tooth - can it work? Endod Topics. 2003;5(1):49-56. 
6. Cianconi L, Palopoli P, Campanella V, Mancini M. Composition and microstructure of MTA and Aureoseal Plus: XRF, EDS, XRD and FESEM evaluation. Eur J Paediatr Dent. 2016;17(4):281-285.

7. Ferracane JL, Cooper PR, Smith AJ. Can interaction of materials with the dentin-pulp complex contribute to dentin regeneration? Odontol. 2010;98(1):2-14.

8. Olsson H, Petersson K, Rohlin M. Formation of a hard tissue barrier after pulp cappings in humans. A systematic review. Int Endod J. 2006;39(6):429-442.

9. Parolia A, Kundabala M, Rao NN, et al. A comparative histological analysis of human pulp following direct pulp capping with Propolis, mineral trioxide aggregate and Dycal. Aust Dent J. 2010;55(1):59-64.

10. Camilleri J, Gandolfi MG. Evaluation of the radiopacity of calcium silicate cements containing different radiopacifiers. Int Endod J. 2010;43(1):21-30.

11. Dionysopoulos D, Tolidis K, Gerasimou P, Koliniotou-Koumpia E. Effects of shade and composition on radiopacity of dental composite restorative materials. Oral Radiol. 2017;33(3):178-186.

12. Watts DC, McCabe JF. Aluminium radiopacity standards for dentistry: An international survey. J Dent.1999;27(1):73-78.

13. Baksi BG, Ermis RB. Comparison of conventional and digital radiography for radiometric differentiation of dental cements. Quintessence Int. 2007;38(9):e532-e536.

14. Souza LC, Yadlapati M, Dorn SO, Silva R, Letra A. Analysis of radiopacity, $\mathrm{pH}$ and cytotoxicity of a new bioceramic material. J Appl Oral Sci. 2015;23(4):383-389.

15. Devito KL, Ortega Al, Haiter-Neto F. Radiopacity of calcium hydroxide cement compared with human tooth structure. J Appl Oral Sci. 2004;12(4):290-293.

16. Antonijevic D, Jevremovic D, Jovanovic S, Obradovic-Djuricic K. An in vitro radiographic analysis of the density of dental luting cements as measured by CCD-based digital radiography. Quintessence Int. 2012;43(5):421-428.

17. Medgovic IM, Antonijevic D. In vitro radiographic density of dental posts measured by digital radiography. Oral Radiol. 2014;30(1):9-12.

18. Pires de Souza FC, Pardini LC, Cruvinel DR, Hamida HM, Garcia LF. In vitro comparison of the radiopacity of cavity lining materials with human dental structures. J Conserv Dent. 2010;13(1):65-70.

19. Bueno CE, Zeferino EG, Manhães LR Jr., Rocha DG, Cunha RS, De Martin AS. Study of the bismuth oxide concentration required to provide Portland cement with adequate radiopacity for endodontic use. Oral Surg Oral Med Oral Pathol Oral Radiol Endod. 2009;107(1):e65-e69.

20. Tanalp J, Karapınar-Kazandağ M, Dölekoğlu S, Kayahan MB. Comparison of the radiopacities of different root-end filling and repair materials. ScientificWorld Journal. 2013;2013:594950.

21. Tanomaru-Filho M, Jorge EG, Tanomaru JMG, Gonçalves M. Evaluation of the radiopacity of calcium hydroxide- and glass-ionomerbased root canal sealers. Int Endod J. 2008;41(1):50-53.

22. Dammaschke T, Stratmann U, Wolff $P$, Sagheri D, Schäfer E. Direct pulp capping with mineral trioxide aggregate: An immunohistologic comparison with calcium hydroxide in rodents. $J$ Endod. 2010;36(5):814-819.

23. Cutajar A, Mallia B, Abela S, Camillleri J. Replacement of radiopacifier in mineral trioxide aggregate; characterization and determination of physical properties. Dent Mater. 2011;27(9):879-891.

24. Laghios CD, Benson BW, Gutmann JL, Cutler CW. Comparative radiopacity of tetracalcium phosphate and other root-end filling materials. Int Endod J. 2000;33(4):311-315.

25. Kim EC, Lee BC, Chang HS, Lee W, Hong CU, Min KS. Evaluation of the radiopacity and cytotoxicity of Portand cements containing bismuth oxide. Oral Surg Oral Med Oral Pathol Oral Radiol Endod. 2008;105(1):e54-e57.

26. Ordinola-Zapata R, Bramante CM, García-Godoy F, et al. The effect of radiopacifiers agents on $\mathrm{pH}$, calcium release, radiopacity, and antimicrobial properties of different calcium hydroxide dressings. Microsc Res Tech. 2015;78(7):620-625.

27. Islam I, Chng HK, Yap AU. Comparison of the physical and mechanical properties of MTA and portland cement. J Endod. 2006;32(3):193-197.
28. Chng HK, Islam I, Yap AU, Tong YW, Koh ET. Properties of a new root-end filling material. J Endod. 2005;31(9):665-668.

29. Danesh G, Dammaschke T, Gerth HU, Zandbiglari T, Schäfer E. A comparative study of selected properties of ProRoot mineral trioxide aggregate and two Portland cements. Int Endod J. 2006;39(3):213-219.

30. Parirokh $\mathrm{M}$, Torabinejad $\mathrm{M}$. Mineral trioxide aggregate: A comprehensive literature review - part I: Chemical, physical, and antibacterial properties. J Endod. 2010;36(1):16-27. 